\title{
FUNGITOXIC ACTIVITY AVALIATION OF THE HEXANE AND METHANOL EXTRACTS OF COPAIBA PLANT LEAVES Copaifera langsdorffi Desfon
}

\author{
Avaliação da atividade fungitóxica dos extratos foliares \\ hexânico e metanólico da Copaifera langsdorffi Desfon \\ Ana Carolina Lourenço Amorim, Maria das Graças Cardoso', \\ José Eduardo Brasil Pereira Pinto ${ }^{3}$, Paulo Estevão de Souza ${ }^{4}$, Nelson Delú Filho ${ }^{5}$
}

\begin{abstract}
The fungitoxicity of hexane and methanol extracts of copaiba plants were evaluated by biological tests against the phytopathogens Colletotrichum gloeosporioides and Bipolaris sorokiniana. These extracts were chosen because they presented the highest yields in the extraction at room temperature. The biological material was obtained from the Department of Phytopathology of the UFLA, transplanted in BDA (C. gloeosporioides) and PCA (B. sorokiniana) culture media and incubated in a germination chamber with control of light and temperature. Five treatments $(0 / 100 / 200 / 400 / 800 \mathrm{ppm})$ were used with three repetitions of each, and four mutually perpendicular radii, were measured in centimeters from the mycelial center. The formula for the Mycelial Growth Index (MGI) was applied to the values obtained for statistical analyses. A $32 \%$ reduction in the growth of B. sorokiniana was observed in the presence of the methanol extract, while the hexane extract was effective against both of the phytopathogens, resulting in a $49 \%$ reduction in the growth of $B$. sorokiniana and an $18 \%$ reduction in the growth of $C$. gloeosporioides.
\end{abstract}

Index terms: Copaiba plants, Colletotrichum gloeosporioides, Bipolaris sorokiniana, biological control.

\section{RESUMO}

Avaliou-se a fungitoxicidade dos extratos hexânico e metanólico do óleo copaíba por meio de ensaios biológicos contra os fitopatógenos Colletotrichum gloeosporioides e Bipolaris sorokiniana. Os referidos extratos foram escolhidos em razão dos melhores rendimentos obtidos na extração a frio. O material biológico foi obtido na UFLA no Departamento de Fitopatologia, repicado em meio de cultura BDA (C. gloeosporioides) e PCA (B. sorokiniana) e incubados em câmara de germinação com controle de temperatura e luz. Empregaram-se cinco tratamentos (0/100/200/400/800 ppm), realizando-se três repetições e avaliando-se quatro raios, medidos em centímetros, a partir do micélio central. Os valores aferidos foram aplicados à fórmula do Índice de Crescimento Micelial (ICM) para as análises estatísticas. Observou-se que o extrato metanólico apresentou uma tendência à redução de $32 \%$ contra o B. sorokiniana, ao passo que o hexânico foi eficaz para ambos os fitopatógenos, apresentado uma tendência à redução de $49 \%$ para o B. sorokiniana e $18 \%$ para o C. gloeosporioides.

Termos para indexação: Óleo copaíba, Colletotrichum gloeosporioides, Bipolaris sorokiniana, controle biológico.

(Recebido para publicação em 28 de abril de 2003 e aprovado em 18 de agosto de 2003)

\section{INTRODUCTION}

With the development of microorganisms resistant to chemicals applied indiscriminately to crops, research has been done with the goal to search for alternative and safe forms of agrochemical pest control without causing any damage to environment and to hu- mans, maintaining the crop qualitatively and quantitatively. Taking into account the economical aspect and human health itself, investigations concerning the biological activity of raw extracts of medicinal plant species or of the essential oil have been researched, they being able, inclusively, replace with safety, either partially or wholly, pesticides, insecticides and fungicides.

\footnotetext{
1. Msc. - Departamento de Química - Universidade Federal de Lavras/UFLA - Caixa Postal 37 - 37200-000 - LAVRAS, MG.

2. Dra. - Departamento de Química/UFLA.

3. Ph.D - Departamento de Agricultura/UFLA

4. Dr. - Departamento de Fitopatologia/UFLA.

5. Dr. - Universidade Vale do Rio Verde de Três Corações - UNINCOR.
} 
Fungi, being regarded as the chief causative agents of plant pathology, therefore, the accomplishment not of only assays utilizing plant extracts or oils is of great value but also to know the mechanism through which, the pathogen reaches the species. Wedge et al. (1999) state that the filamentous fungi of the genus Colletotrichum, Botrytis, Fusarium and Phomopsis are regarded as phytopathogenic organisms, resulting into great economical losses.

According to Cimanga et al. (2002), a number of medicinal plants have revealed a few interesting activities as, for example, with several already isolated secondary metabolites. Some classes of secondary metabolites have been widely employed for biological control of phytopathogens as terpenoids, alkaloids, saponins, amines, amides, fatty acids, long alkene chains, phenolic compounds, flavonoids, xanthones and benzoquinones (HARBONE, 1994).

Several works report sesquiterpenes, chiefly lactonic, extracted from essential oils, as secondary metabolites which present a recognized fungitoxic activity. Among these, the research by Harbone (1994) is quoted, which confirm the fungitoxic action of those molecules, showing that $62 \%$ of the quoted tested metabolites present partial inhibitory activity and that a half presents a high inhibitory activity against pathogenic fungi. Afterwards, Wedge et al. (1999) utilized 36 natural and synthetic lactonic sesquiterpenes against pathogenic fungi such as Colletotrichum acutatum, C. fragariae, C. gloeosporoides, Fusarium oxysporum, Botrytis cinerea and Phomopsis sp. With promising results. In the chemical composition of medicinal plants, there are substances which may act on the interactions between the plant species and the phytopathogen, secondary metabolites, acting as an activator of the host plant's defense system or directly against fungal pathogens. The secondary metabolites present in medicinal plants with bioactivity against fungi, generally show an poisonless character to humans and animals, increased fungitoxic action and less phytotoxicity, as compared with synthetic fungicides (SANTOS, 1996).

Among different fungal pathogens, the genus Colletotrichum stands out, the second greatest etiologic causative agent of fungus-caused diseases in the region of Lavras (Minas Gerais), with about $10.5 \%$ (POZZA et al., 1999). It is a phytopathogen with a cosmopolite geographic range and reaches several families, mainly tropical and subtropical fruit trees (GOES, 1995)
The fungus $C$. gloeosporioides figura as a causal agent of number diseases, among them, stem rot (podridao peduncular), chief causative agent of losses at post-harvest of the papaya and anthracnose in the leaves of the papaya tree and pupunheira (Bactris gasipaes Kunt), an species of great economical importance for Amazon region, owing to being utilized for palmetto production and yielding eatable fruit (DICKMAN et al., 1982; VERAS and YUYAMA, 2000; SILVA et al., 2001).

The symptoms provoked by anthracnose on papaya fruit caused by $C$. gloeosporioides are characterized at first by the appearance of small aqueous, circular and surface spots. When these lesions are present in a great, they may join together and form extensive areas of rotting (SILVA, 1988). The fungus is still causative agent of the disease named "fall of the young fruit" chiefly in the genus Citrus (GOES, 1995; SANTOS, 1996).

Other highly important phytopathogen is Bipolaris sorokiniana or Helminthosporium sativum, for take place mainly in wheat crops (Triticum aestivum L.) affecting the aerial and radicular organs and causing consequently helminthsporiosis or brown spot, it being therefore, an important pathogen associated with wheat seeds (PESSOA, 1993; BACH, 1997). It is found in the wheat-growing regions of the country, such as São Paulo, Minas Gerais, Paraná, Mato Grosso do Sul, Rio Grande do Sul and Federal District (BRAGA, 1987; FORCELINI, 1992; PESSOA, 1993).

According to Braga (1987) the early symptoms of helminthsporiosis provoked by B. sorokiniana are egg-shaped leaf spots, dark brown to black in coloration. The severely hit ones undergo early abscission, their cortical and sheath tissues are affected resulting into a dark dusky coloration, corresponding to the necrotized tissues, in addition, the root system is affected leading to its rotting. Forcelini (1992) reports that heminthosporiosis lesions also may be found on the nodes and internodes, causing in certain cases the constriction of the affected area with the consequent breakage and death of the plant.

\section{MATERIAL AND METHODS}

\section{Fungal Species}

Were utilized the fungi Bipolaris sorokiniana e Colletotrichum gloeosporioides isolated from Phytopathology Department fungus collection, of the Federal Univer- 
sity of Lavras. The cultures were transplanted every seven days for obtaining new colonies.

For the mycelia growth, the pathogens were cultivated in culture media, BDA (potato, dextrose and agar) specific to Colletotrichum gloeosporioides and PCA (potato, carrot and agar) to Bipolaris sorokiniana. The quoted culture media were chosen for promoting the best production of spores to each phytopathogen.

The pathogens were grown in a previously melted medium, placed into $10 \mathrm{~cm}$ diameter Petri dish (process accomplished in a laminar flux chamber) and incubated in a germination chamber at a temperature of 20 to $22^{\circ} \mathrm{C}$, under a 12 -hour photoperiod.

\section{Preparation of the standard solutions}

The raw extracts utilized for verifying of fungal inhibition were the methanol and hexane extract, obtained by means of the cold extraction. In this extracting process preconized by Matos (1988), 250 grams of ventilated oven-dried leaves were utilized, which were soaked in hexane over an 8 days period, in air-tightly closed container. Later, the liquid was filtered and rotaevaporated, obtaining the hexane extract. The leaves, still with the residue of hexane, vulgarly called "cake", were submitted to oven-drying and re-utilized by utilizing the following solvents in succession: ethyl acetate, chloroform, ethanol and methanol, obeying to the same method performed with hexane. The hexane and methanol extracts were chosen due to presenting greater yield in the extracting process accomplished. The concentrations tested were 100, 200, 400 and $800 \mathrm{ppm}$, equaling with the control (0 ppm).

The standard solutions (solutions obtained from the extracts and which were applied into the culture medium) of the methanol extract were solubilized in $10 \mathrm{~mL}$ of both distilled and autoclaved water, whereas for the hexane extract, it was solubilized with $1 \mathrm{~mL}$ de propanone. Therefore, for the check of the hexane extract, the $10 \%$ propanone solution was added to the culture medium.

\section{Evaluation of mycelial growth}

For the set-up of the experiments, mycelial disks $4 \mathrm{~mm}$ in diameter were inserted in the center of the Petri dish containing the culture medium already solubilized with the standard solution obtained from the extracts (hexane and methanol). The dishes sealed with the aid of a plastic film and incubated in germination chambers at the temperature of $22 \pm 2^{\circ} \mathrm{C}$ and 12-hour photoperiod. Three replicates were accomplished for each concentration. For evaluation of growth, four perpendicular rays on the second, fourth and sixth days were conferred (Figure 01).

The 20 treatments were obtained from the combination of two plant extracts at five concentrations were applied on two fungus species. The completely randomized with three replicates was utilized. The results obtained were transformed in Mycelial Growth Index by making use of the formula modified by Nacagava Maguire, adapted by Oliveira (1991).

$$
\mathrm{ICM}=\frac{\mathrm{C}_{1}}{\mathrm{~N}_{1}}+\frac{\mathrm{C}_{2}}{\mathrm{~N}_{2}}+\frac{\mathrm{C}_{\mathrm{n}}}{\mathrm{N}_{\mathrm{n}}}
$$

Where :

ICM: Mycelial Growth Index;

$\mathrm{C}_{1}, \mathrm{C}_{2}, \mathrm{C}_{\mathrm{n}}$ : mycelium growth, on the second, fourth and sixth day;

$\mathrm{N}_{1}, \mathrm{~N}_{2}, \mathrm{~N}_{\mathrm{n}}$ : number of days.

After transformed, the results were submitted to analyses of variance and regression. The linear, quadratic and cubic effects of the polynomial model $\left[\mathrm{Y}=\mathrm{a}+\mathrm{b} \mathrm{x}+\mathrm{b}_{1}\right.$ $\left.x^{2}+b_{2} x^{3}\right]$ and square root of the polynomial model, namely $\left[\mathrm{Y}=\mathrm{a}+\mathrm{b} \mathrm{x}^{0,5}+\mathrm{b}_{1} \mathrm{x}+\mathrm{b}_{2} \mathrm{x}^{1,5}\right]$. It was selected, within each group of equations with the same number of estimated parameters, the one of significant effect by the $\mathrm{F}$ test at $5 \%$ of probability, of biological of greatest square sum, namely, larger $\mathrm{R}^{2}$, evaluating the means of the qualitative effect, fungal species and sorts of extracts.

\section{RESULTS AND DISCUSSION}

The mean results obtained from of the colonies of the isolates of the fungi submitted to five concentrations of the methanol and hexane plant extracts are in Table 1. 
TABLE 1 - Mean results (means of three replicates) of the Mycelial Growth Index (ICM) of two fungi submitted to five concentrations of two plant extracts.

\begin{tabular}{|c|c|c|c|}
\hline Extracts & Conc. & Fungi & ICM \\
\hline Methane & 0 & Colletotrichum gloeosporioides & 1,76 \\
\hline Methane & 100 & C. gloeosporioides & 1,69 \\
\hline Methane & 200 & C. gloeosporioides & 1,64 \\
\hline Methane & 400 & C. gloeosporioides & 1,65 \\
\hline Methane & 800 & C. gloeosporioides & 1,74 \\
\hline Methane & 0 & Bipolaris sorokiniana & 1,69 \\
\hline Methane & 100 & B. sorokiniana & 1,63 \\
\hline Methane & 200 & B. sorokiniana & 1,52 \\
\hline Methane & 400 & B. sorokiniana & 1,51 \\
\hline Methane & 800 & B. sorokiniana & 1,13 \\
\hline Hexane & 0 & C. gloeosporioides & 2,40 \\
\hline Hexane & 100 & C. gloeosporioides & 2,28 \\
\hline Hexane & 200 & C. gloeosporioides & 2,27 \\
\hline Hexane & 400 & C. gloeosporioides & 2,12 \\
\hline Hexane & 800 & C. gloeosporioides & 1,96 \\
\hline Hexane & 0 & B. sorokiniana & 2,13 \\
\hline Hexane & 100 & B. sorokiniana & 2,00 \\
\hline Hexane & 200 & B. sorokiniana & 1,82 \\
\hline Hexane & 400 & B. sorokiniana & 1,78 \\
\hline Hexane & 800 & B. sorokiniana & 1,12 \\
\hline
\end{tabular}

It is found in Table 01, which there was an initial reduction trend and of the means of the Mycelial Growth Index (ICM) of the colonies of the fungus $C$. gloesporioides with the increase of the concentrations of the methanol extract up to the concentration of 200 ppm. However, for the fungus B. sorokiniana there was a reduction of the ICM in every treatment. By the use of the hexane extract, it was observed that with increasing concentrations, there was a redaction of the ICM in the two species of fungi tested.

It is worthwhile standing out, based upon the data of table 01, which the methanol extract presented a greater reduction trend of the mycelial growth as compared with the hexane extract, occurring for both fungi. Likely, this corroboration is due to the fact that in me- thanol extracts there is the preferential extraction of polar chemical components, such as phenolic components which present proved antifungal action.

In Table 2, it is observed that there was no significant difference among the ICM means obtained with the methanol and hexane extracts in the absence of extract $(0 \mathrm{ppm})$ and at the concentrations of 100 and of $200 \mathrm{ppm}$; at the concentrations of 400 and of $800 \mathrm{ppm}$, the means of the ICM obtained with extracts were significantly inferior to those obtained with methanol extracts.

Observing Table 3, one may infer that the means of the ICM obtained with the methanol extract were significantly superior to those obtained with the hexane extract for the phytopathogen $B$. sorokiniana, at the five concentrations investigated. 
TABELA 2 - Mean results (means of three replicates) of the Mycelial Growth Index for Colletotrichum gloeosporioides submitted to four concentrations of two plant extracts.

\begin{tabular}{cccccc}
\hline \multicolumn{7}{c}{ Concentrations } \\
\hline Extracts & $\mathbf{0}$ & $\mathbf{1 0 0}$ & $\mathbf{2 0 0}$ & $\mathbf{4 0 0}$ & $\mathbf{8 0 0}$ \\
\hline Methanol & $1,76 \mathrm{a}$ & $1,69 \mathrm{a}$ & $1,64 \mathrm{a}$ & $1,65 \mathrm{a}$ & $1,74 \mathrm{a}$ \\
\hline Hexane & $1,69 \mathrm{a}$ & $1,63 \mathrm{a}$ & $1,52 \mathrm{a}$ & $1,51 \mathrm{~b}$ & $1,13 \mathrm{~b}$ \\
\hline
\end{tabular}

* Means followed by a same letter in each column do not differ significantly from each other at $5 \%$ of probability by the $\mathrm{F}$ test.

TABLE 3 - Mean results (means of three replicates) of the Mycelial Growth Index for Bipolaris sorokiniana submitted to four concentrations of two plant extracts.

\begin{tabular}{cccccc}
\hline \multicolumn{7}{c}{ Concentrations } \\
\hline Extracts & $\mathbf{0}$ & $\mathbf{1 0 0}$ & $\mathbf{2 0 0}$ & $\mathbf{4 0 0}$ & $\mathbf{8 0 0}$ \\
\hline Methanol & $2,40 \mathrm{a}$ & $2,28 \mathrm{a}$ & $2,27 \mathrm{a}$ & $2,12 \mathrm{a}$ & $1,96 \mathrm{a}$ \\
\hline Hexane & $2,13 \mathrm{~b}$ & $2,00 \mathrm{~b}$ & $1,82 \mathrm{~b}$ & $1,78 \mathrm{~b}$ & $1,12 \mathrm{~b}$ \\
\hline
\end{tabular}

** Means followed by a same letter in each column do not differ significantly from each other at $5 \%$ of probability by the $\mathrm{F}$ test.

In Figure 1 it is found that the increase of the concentrations of the concentrations of the methanol extract brought about reduction of the ICM of the fungus $B$. sorokiniana of 1.69 in the absence of the extract to 1.13 at the concentration of $800 \mathrm{ppm}$, namely, reduction of $32 \%$ of the ICM. Nevertheless for the fungus $C$. gloesporioides the ICM past from 1.76 in the absence of the extract to a minimum value of 1.64 at the concentration of $200 \mathrm{ppm}$ of the extract, increasing, next, to $1.73 \mathrm{ICM}$ at the concentration of $800 \mathrm{ppm}$ of the methanol extract. On the other hand, the increase of the concentrations of the hexane extract brought about reduction of the ICM in the two species of fungi. There were reductions of $18 \%$ (2.4 to 1.96) for the fungus C. gloesporioides and of $49 \%$ (2.13 to 1.12 ) for the fungus $B$. sorokiniana when the concentration of the hexane extract was increased from zero to $800 \mathrm{ppm}$ (Figure 2).

Comparing Figures 1 and 2, a greater inhibition for both the fungi is found by utilizing the hexane extract. It is known that hexane extract preferentially re- sins, oils and waxes and therefore, some of these classes of metabolites may be responsible for inhibitory action. A research published by Diniz et al. (1996) evaluated the fungitoxic action of copaíba balsam against the Fusarium moniliforme and Alternaria sp. confirming a drastic reduction to the development of the spores of the fungi of these phytopathogens. The quoted author verified also that copaíba oil promoted modifications in the natural pigmentation of the fungi, suggesting an action in their secondary metabolism. Thus, it is inferred that the same is taking place in the biologic assays performed on Bipolaris sorokiniana (Figure 3A and 3B) and on Colletotrichum gloeosporioides (Figure 4A and 4B).

It is worthwhile to stress that in spite of the trend, inhibition against $C$. gloeosporioides by utilizing the methanol, occurring up to $200 \mathrm{ppm}$, it is believed that the later growth had happened as a attempt of the reported phytopathogen to survive to survive the action of the extract, with the modification of its metabolism, confirmed by its pigment modification. 

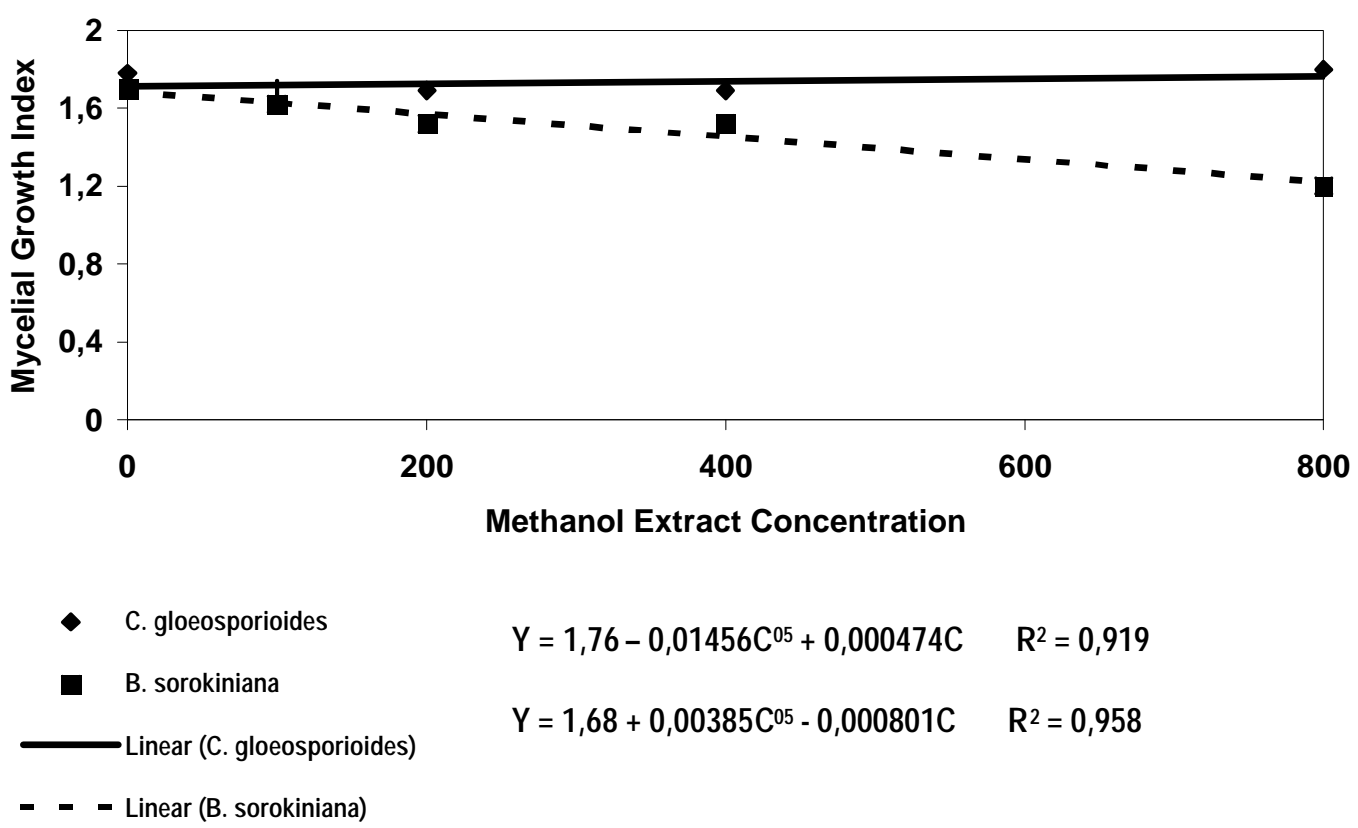

FIGURA 1 - Effect of the concentrations of the methanol extract upon the mycelial growth index of the isolates of Colletotrichum gloeosporioides and Bipolaris sorokiniana (AMORIM, 2003).

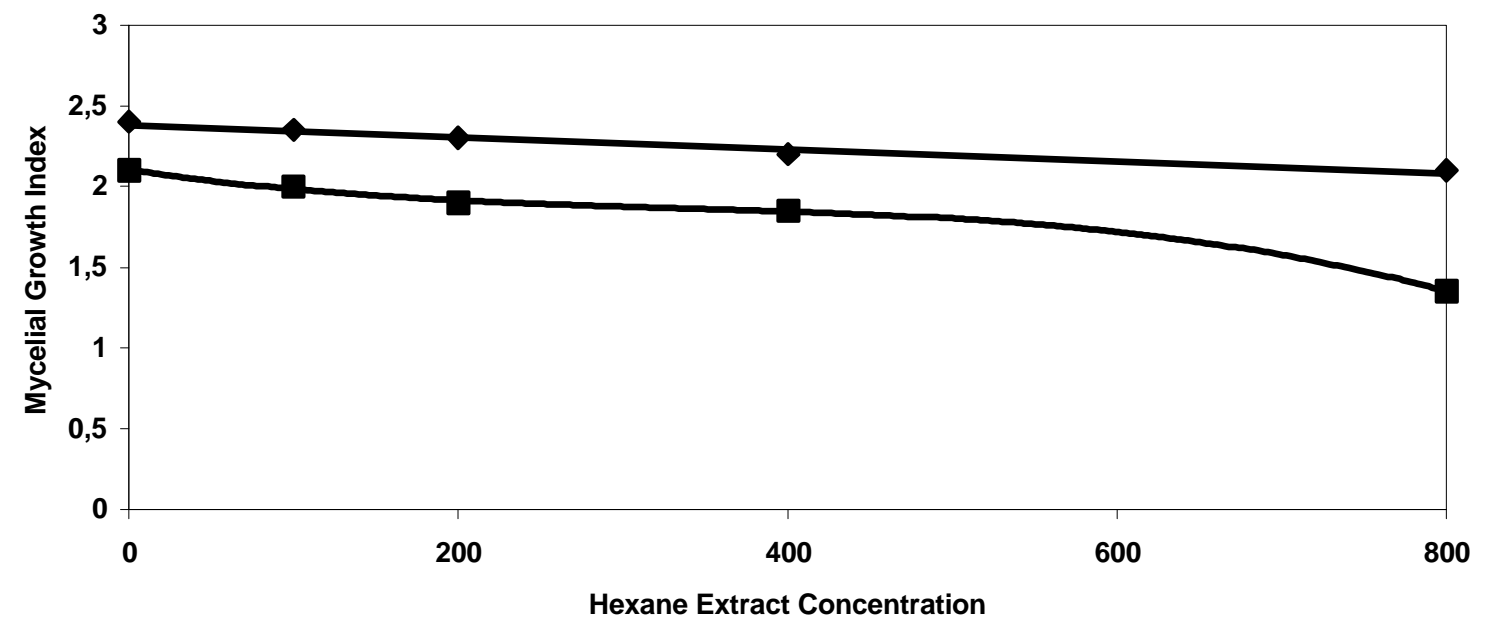

C. gloeosporioides

- B. sorokiniana

$Y=2,36-0,00053 C^{05}$

$R^{2}=0,964$

Polinômio (B. sorokiniana)

$Y=4,14-0,00236 C^{05}-0,000058 C^{2}$

$R^{2}=0,994$

—Linear (C. gloeosporioides)

FIGURE 2 - Effect of the concentrations of the hexane extract upon the Mycelial Growth Index of the isolates of Colletotrichum gloesporioides and Bipolaris sorokiniana (AMORIM, 2003). 


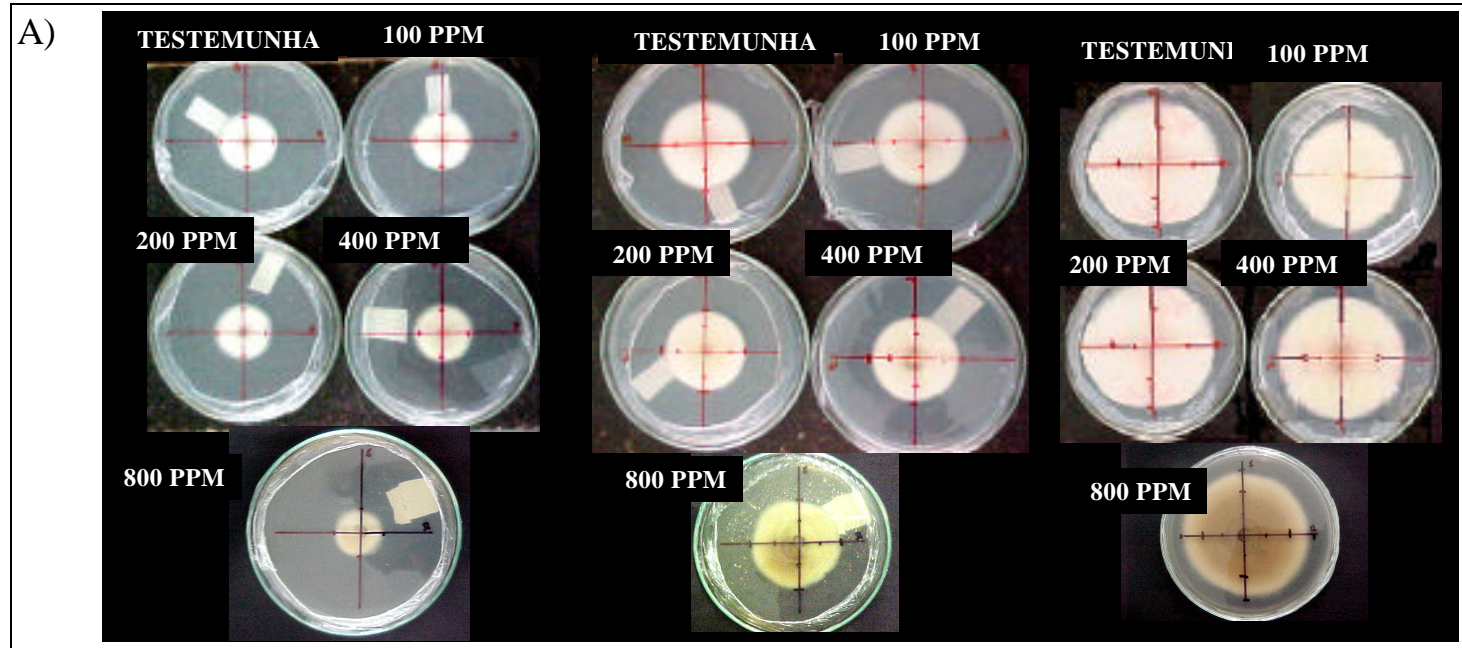

B)

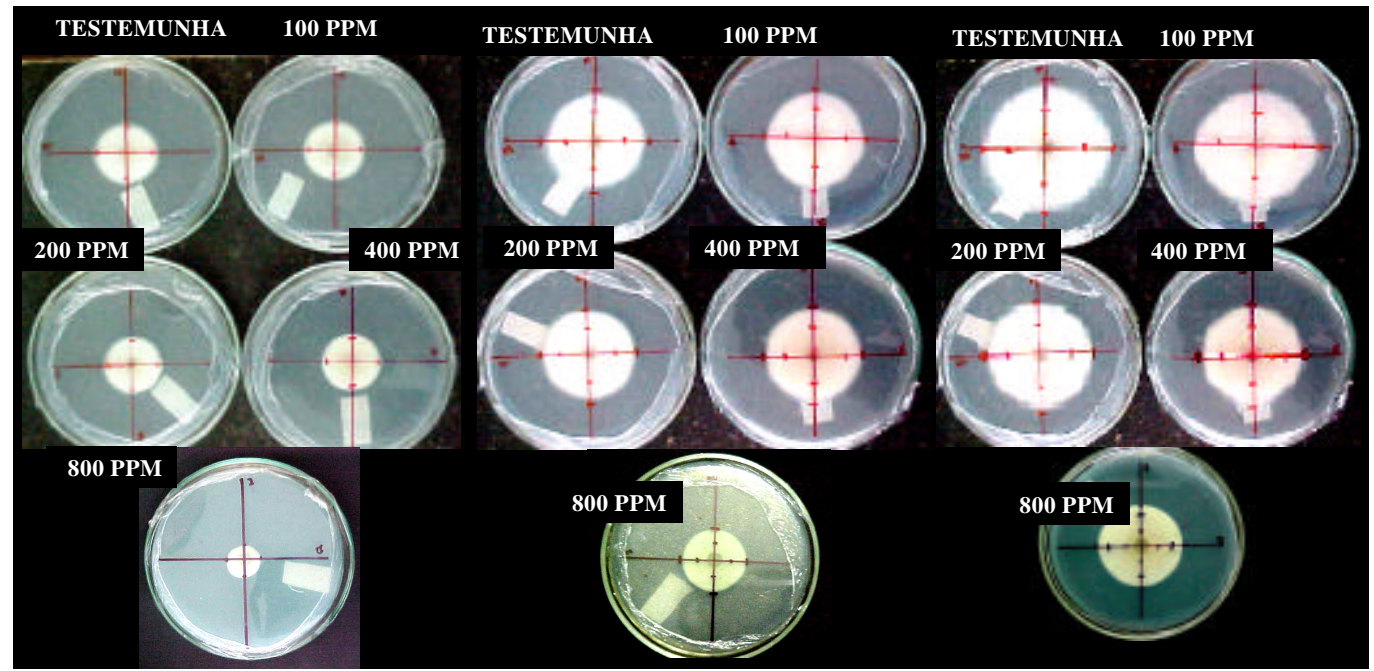

FIGURE 3 - A) Mycelial growth of Bipolaris sorokiniana on the 2 nd, $4^{\text {th }}$ and 6 th day utilizing the methanol extract; B) Mycelial growth of $B$. sorokiniana on the $2 \mathrm{nd}, 4^{\text {th }}$ and $6^{\text {th }}$ day by utilizing the hexane extract. Contrast the individual the tests with control (testemunha). 


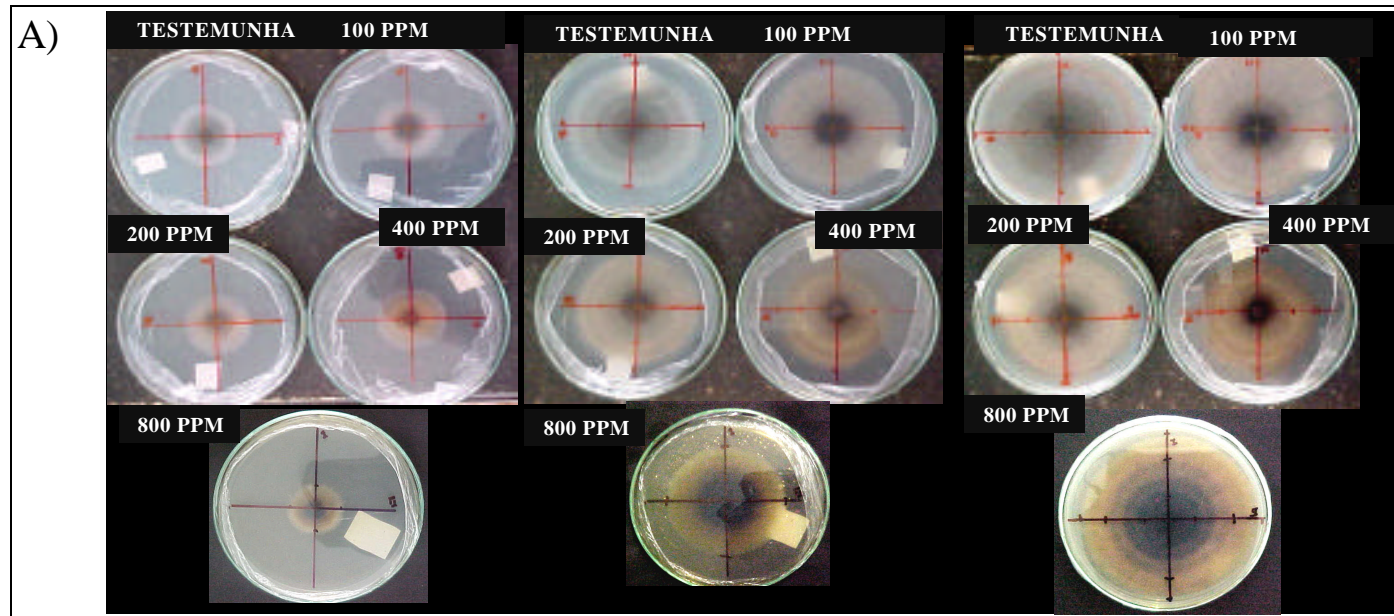

B)

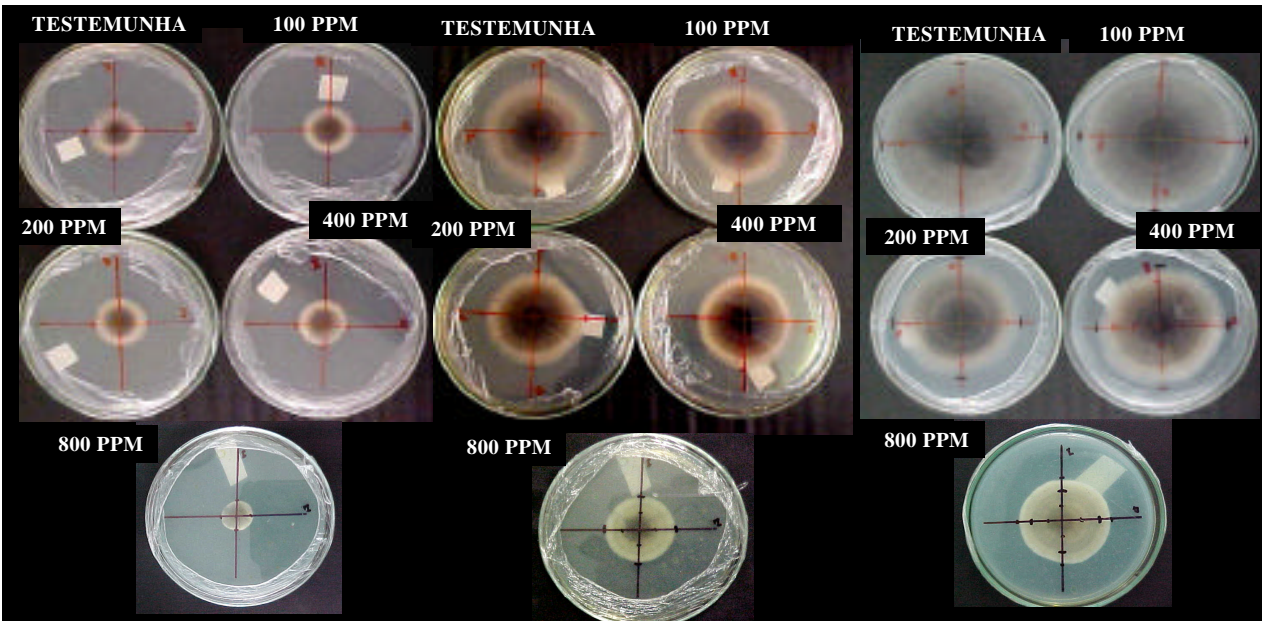

FIGURE 4 - A) Mycelial growth of Colletotrichum gloeosporioides utilizing the methanol extract. B) Mycelial growth of $C$. gloeosporioides on the $2^{\text {nd }}, 4^{\text {th }}$ and $6^{\text {th }}$ day by utilizing the hexane extract. Contrast the individual the tests with control (testemunha).

\section{CONCLUSIONS}

The hexane extract at the concentration of 100 to $800 \mathrm{ppm}$, promoted an inhibition trend of $18 \%$ of the ICM for the fungus C. gloeosporioides and of $49 \%$ for B. sorokiniana.

The methanol extract, at the concentration of 100 to $800 \mathrm{ppm}$, promoted an inhibition trend of $32 \%$ of the ICM of B. sorokiniana and of 1.76 to 1.64 , from 0 to $200 \mathrm{ppm}$, for $C$. gloeosporioides.

\section{ACKNOWLEDGEMENTS}

We are thankful to CNPq for the financial support and grant to Prof ${ }^{\mathrm{a}}$. Dr ${ }^{\mathrm{a}}$. Maria das Graças Cardo- so, to the Chemistry Department to allow the accomplishment of the extracts utilized, to the Phytopathology Department, which enabled the accomplishment of the biological assays and to Prof. Dr. Paulo Fernando Trugilho, for the borrowing of the materials necessary of evaluation of the biological activities.

\section{BIBLIOGRAPHIC REFERENCES}

AMORIM, A. C. L. Caracterização química da Copaífera langsdorffi e avaliação de sua atividade fungitóxica. 2003. 94 p. Dissertação (Mestrado em Agroquímica) - Universidade Federal de Lavras, Lavras, 2003. 
BACH, E. E. Distinção morfológica e isoenzimática de Bipolaris spp. e Drechslera tritici-repentis do trigo: aspectos bioquímicos das interações e indução da resistência. 1997. 150 f. Tese (Doutorado em Agronomia) Escola Superior de Agricultura Luiz de Queiroz, Piracicaba, 1997.

BRAGA, J. B. Variação de Bipolaris sorokiniana (Sacc. In Sorok.) Shoem. associado a sementes de trigo (Triticum aestivum $\mathbf{L}$.) procedentes de algumas áreas do estado de Minas Gerais. 1987. 61 f. Dissertação (Mestrado em Agronomia) - Escola Superior de Agricultura Luiz de Queiroz, Piracicaba, 1987.

CIMANGA, K.; KAMBU, K.; TONA, L.; APERS, S.; BRUYNE, T. de; HERMANS, N.; TOTTÉ, J.; PIETERS, L.; VLIETINCK, A. J. Correlation between chemical composition and antibacterial activity of essential oils of some aromatic medicinal plants growing in the Democratic Republic of Congo. Journal of Ethnopharmacology, Lausanne, v. 79, p. 213-220, 2002.

DINIZ, S. P. S. S.; LOZANO, V.; REZENDE, D.; TONA, N.; SOUZA, L. S. Ação do bálsamo de copaíba no controle do desenvolvimento de Fusarium moliniforme e Alternaria sp. Fitopatologia Brasileira, Brasília, v. 21, ago. 1996. Suplemento.

FORCELINI, C. A. Incidência, transmissão e controle de Bipolaris sorokiniana em sementes de trigo. 1992. 114 f. Dissertação (Mestrado em Ciências) - Escola Superior de Agricultura Luiz de Queiroz, Piracicaba, 1992.

GOES, A. de. Queda prematura dos frutos cítrico: caracterização do agente causal, Colletotrichum gloeosporioides PENZ. [SENSU ARX, 1957], e controle da doença. 1995. 143 f. Tese (Doutorado em Agronomia) - Escola Superior de Agricultura Luiz de Queiroz, Piracicaba, 1995.

HARBONE, J. B. Plant phenolics. In: MANN, J.; DAVISON, R. S.; HOBBS, J. B.; BANTHORPE, D. V.; HARBONE, J. B. (Eds.). Natural products: their chemistry and biological significance. Essex: Longman, 1994.

MATOS, F. J. A. Introdução à fitoquímica experimental. Fortaleza: UFC, 1988. 128 p.
OLIVEIRA, J. A. Efeito de tratamento fungicida em sementes e no controle de tombameto de plântulas de pepino (Cucumis sativas L.) e pimentão (Capsicum anannum L.). 1991. 81 f. Dissertação - (Mestrado em Fitossanidade) - Escola Superior de Agricultura de Lavras, Lavras, 1991.

PESSOA, M. N. G. Controle biológico de Bipolaris sorokiniana Sacc. ex Sorok. em sementes de trigo (Triticum aestivum L.). 1993. 134 f. Dissertação (Mestrado em Agronomia) - Escola Superior de Agricultura Luiz de Queiroz. Piracicaba, 1993.

POZZA, E. A.; SOUZA, P. E. de; CASTRO, H. A. de. Frequência da ocorrência de doenças da parte aérea de plantas na região de Lavras-MG. Ciência e Agrotecnologia, Lavras, v. 23, n. 4, p. 1001-1005, out./dez. 1999.

SANTOS, M. M. F. B. dos. Efeito de extratos de duas formas de Lippia alba sobre o fungo Colletotrichum gloeosporioides (PENZ.), isolado de Citrus sp. 1996. 105 f. Dissertação (Mestrado em Ciências) - Escola Superior de Agricultura Luiz de Queiroz, Piracicaba, 1996.

SILVA, F. A. N.; MACHADO, J. da C.; LIMA, L. C. de O.; RESENDE, M. L. V. de; Controle químico da podridão peduncular de mamão causada por Colletotrichum gloeosporiodes. Ciência e Agrotecnologia, Lavras, v. 25, n. 3, p. 519-524, maio/jun. 2001.

SILVA, T. M. W. Tratamento térmico e radiação gama no contrle de Colletotrichum gloesporioides [PENZ.] PENZ. Et Sacc., agente causal da Antracnose em frutos de mamoeiro (Carica papaya L.). 1988. 155 f. Dissertação (Mestrado em Agronomia) Escola Superior de Agricultura Luiz de Queiroz, Piracicaba, 1988.

VERAS, S. M.; YUYAMA, K. Severidade de doenças foliares da pupunheira em diferentes períodos climáticos, níveis de adubação e espaçamentos. Fitopatologia Brasileira, Belém, v. 25, p. 433, ago. 2000. Suplemento.

WEDGE, D. E.; GALINDO, J. C. G.; MACIAS, F. A. Fungical acitivity of natural and synthetic sesquiterpene lactone analog. Phytochemistry, Oxford, v. 53, n. 7, p. 747-757, Apr. 1999. 